\title{
Evaluation of the Nutritional and Storage Quality of Meatballs Formulated with Bee Pollen
}

\author{
Sadettin Turhan*, Fehmi Yazici, Furkan Turker Saricaoglu, Mustafa Mortas, and Huseyin Genccelep \\ Department of Food Engineering, OndokuzMayis University, 55139 Samsun, Turkey
}

\begin{abstract}
In this study, the nutritional and storage quality of meatballs formulated with different levels $(0,1.5,3.0,4.5$ and $6.0 \%)$ of bee pollen were investigated during storage at $41^{\circ} \mathrm{C}$ for $9 \mathrm{~d}$. Protein content of meatballs increased, while moisture content decreased with increased pollen. The addition of pollen improved cooking loss but decreased the redness (Hunter $a$ value) and sensory scores. Textural parameters (hardness, springsness, gumminess, and chewiness) were affected by pollen addition and the hardness and gumminess values of meatballs decreased as the pollen content increased. While C18:0 content of meatballs slightly decreased with pollen addition, C18:2n-6c, C18:3n-3, C20:5n-3, and PUFA contents increased. The PUFA/ saturated fatty acids $(\mathrm{P} / \mathrm{S})$ ratio increased from 0.05 in the control to 0.09 in meatballs with $6.0 \%$ pollen. The $n-6 / n-3$ ratio decreased from 11.84 in the control to 3.65 in the meatballs with $6.0 \%$ pollen. The addition of pollen retarded the lipid oxidation and inhibited the bacterial growth in meatballs. The $\mathrm{pH}$, redness, TBA value and total aerobic mesophilic bacteria, coliform bacteria and $S$. aureus counts values changed significantly during storage. The results suggest that bee pollen could be added to enhance the nutritional and storage quality of meatballs with minimal changes in composition and/or sensory properties.
\end{abstract}

Keywords: meatball, bee pollen, nutritional quality, storage quality

\section{Introduction}

Meatballs are common meat products processed from lower-value trimmed red meat to produce a high-value meat product (Dzudie et al., 2004). Like any other food, these products also contain elements (fat, cholesterol, salt, nitrite, phosphate, residues from environmental pollution or the use of pharmaceuticals, contaminants from disinfectants or detergents, toxic compounds formed during cooking, etc.) which in certain circumstances and in inappropriate proportions have a negative effect on human health (Jimenez-Colmenero et al., 2001). This unfortunate situation derives mainly from the content of fat, saturated fatty acids, and cholesterol and their association with cardiovascular diseases, some types of cancer and obesity (Bilek and Turhan, 2009; Fernandez-Gines et al., 2005). There are diverse possible strategies for developing healthier meat products. Reformulation of meat products is one of the strategies (Arihara, 2006; Fernandez-

\footnotetext{
*Corresponding author: Sadettin Turhan, Department of Food Engineering, Engineering Faculty, Ondokuz Mayis University, 55139 Samsun, Turkey. Tel: +90-362-312-1919/1506; Fax: +90-362-457-6034, E-mail: sturhan@omu.edu.tr
}

Gines et al., 2005; Jimenez-Colmenero et al., 2001). Much attention in recent years has been focused on this application to improve nutritional and storage quality of meatballs (Aleson-Carbonell et al., 2005; Bilek and Turhan, 2009; Choe et al., 2011; Huang et al., 2005; Johnston et al., 2005; Sanchez-Escalante et al., 2003; Turhan et al., 2007, 2009).

Bee pollen is a fine powder-like material produced by flowering plants pollen, mixed with nectar and bee secretions and gathered by honey-bees (Graikou et al., 2011). This apicultural product has been used in the human diet for many centuries, due to its nutritional properties and health benefits (Freire et al., 2012; Negri et al., 2011; Rzepecka-Stojko et al., 2012). It is the source of numerous biologically active substances. The most important groups of chemical compounds in bee pollen are the following: proteins and amino acids, carbohydrates, lipids and fatty acids, vitamins, minerals, phenolic compounds, flavonoids, phytosterols and phytochemicals (Morais et al., 2011; Rzepecka-Stojkoet al., 2012). Phytochemicals, such as phenolic compounds are considered beneficial for human health since they decrease the risk of degenerative diseases by reducing oxidative stress and inhibiting macromolecular oxidation. They have been shown to possess 
free-scavenging and metal chelating activity in addition to their reported anticarcinogenic properties. Bee pollen has also been successfully used for the treatment of some cases of benign prostatis and for oral desensitization of children who have allergies (Morais et al., 2011). The biological activity of bee pollen is related to its high antioxidative potential due to the presence of polyphenols, including flavonoids (Rzepecka-Stojko et al., 2012).

There is little information on the use of bee products in meat products. Johnston et al. (2005) studied the antioxidant capabilities of clover and wildflower honeys in delaying lipid oxidation in cooked and reheated ground beef patties stored in refrigerated and frozen states, and suggested honey may be a natural alternative to phosphates to delay lipid oxidation. Nagai et al. (2006) reported the effect of honey species (honey, propolis, royal jelly) on storage of meat, and they showed that honey species exhibited the inhibition of bacterial growth. To the best of our knowledge, there are no reports on the usage of bee pollen in meatballs to improve nutritional and storage quality of product. Therefore, the object of the present study was to evaluate the nutritional (proximate composition, cooking loss, textural and sensorial properties, fatty acid composition) and storage quality ( $\mathrm{pH}$, color, TBA value, microbiological properties) of meatballs formulated with different levels $(0,1.5,3.0,4.5$ and $6.0 \%$ ) of bee pollen.

\section{Materials and Methods}

\section{Materials}

Ground beef (moisture $63.45 \%$, protein $15.20 \%$, fat $18.93 \%$ and ash $0.92 \%$ ), beef fat (moisture $12.97 \%$ and fat $86.32 \%$ ), bee pollen (moisture $21.86 \%$, protein $21.90 \%$, fat $5.33 \%$, ash $2.45 \%$, carbohydrate $48.46 \%$, Hunter $L$ $50.58, a 8.22$ and $b 26.98)$, salt and garlic powder were used as raw materials. Ground beef and beef fat were purchased from a butcher shop. Bee pollen was obtained from Fanus Gida ve Organik Urunler San. Tic. Ltd. Sti.,
Turkey and used in the form of flour after being ground in a mortar. Salt and garlic powder were purchased from a local market. The fatty acid composition $(\mathrm{g} / 100 \mathrm{~g}$ fatty acids) of beef fat and bee pollen was determined by gas chromatography. Beef fat contained C10:0 (0.05), C12:0 (0.05), C13:0 (0.02), C14:0 (2.99), C14:1 (0.45), C15:0 (0.44), C16:0 (28.04), C16:1 (2.04), C17:0 (1.61), C17:1 (0.67), C18:0 (31.17), C18:1n-9c,t (29.07), C18:2n-6t (0.14), C18:2n-6c (2.67), C18:3n-3 (0.23), C20:0 (0.20), C20:1n-9 (0.08), C20:2 (0.02), C20: 3n-6 (0.02), C20:4n$6(0.04)$ and $C 22: 0(0.03)$. Bee pollen contained C6:0 (0.18), C8:0 (0.16), C10:0 (0.40), C12:0 (0.41), C14:0 (0.73), C14:1 (0.12), C15:0 (0.15), C15:1 (1.52), C16:0 (25.63), C16:1 (0.25), C17:0 (0.28), C18:0 (3.73), C18: 1n-9c,t (12.92), C18:2n-6c (22.11), C18:3n-3 (25.87), C20:0 (0.98), C20:1n-9 (0.28), C20:2 (0.21), C20 :5n-3 (0.97), C22:0 (2.26), C23:0 (0.56) and C24:0 (0.28). All chemicals were used the analytical grade.

\section{Preparation of meatballs}

Ground beef was divided into five batches. The first batch was used as control, and the other batches were supplemented with different levels of bee pollen $(1.5 \%$ bee pollen for the second batch, $3.0 \%$ bee pollen for the third batch, $4.5 \%$ bee pollen for the fourth batch and $6.0 \%$ bee pollen for the fifth batch) and adjusted to a fat content of $20 \%$ by the addition of beef fat. In addition, $15 \%$ stale bread, $1.5 \%$ salt and $1 \%$ garlic powder were added to each batch (Table 1). Batches of $1 \mathrm{~kg}$ of each formulation were mixed by hand with gloves for $5 \mathrm{~min}$, weighed into 30-35 g portions, and shaped by hand with gloves. The meatballs were then packaged in polyamide bags (Aksedef Plastic, Turkey) and stored at $4 \pm 1^{\circ} \mathrm{C}$ a home-type refrigerator for $9 \mathrm{~d}$. Samples were randomly drawn for analysis at the evaluation periods. The $\mathrm{pH}$, color, TBA value and microbial growth were analysed on 1 , 3, 6 and $9 \mathrm{~d}$ of storage. Proximate composition, cooking loss, texture profile analysis, sensory properties and fatty acid composition of samples were evaluated on $1 \mathrm{~d}$ of

Table 1. Formulation of meatballs formulated with different levels of bee pollen

\begin{tabular}{cccccc}
\hline \hline \multirow{2}{*}{ Ingredients $(\%, w / w)$} & \multicolumn{5}{c}{ Bee pollen level (\%) } \\
\cline { 2 - 6 } & Control & 1.5 & 3.0 & 4.5 & 6.0 \\
\hline Ground beef & 76.0 & 74.2 & 72.4 & 70.6 & 68.8 \\
Beef fat & 6.5 & 6.8 & 7.1 & 4.5 & 7.7 \\
Bee pollen & - & 1.5 & 3.0 & 1.5 & 6.0 \\
Salt & 1.5 & 1.5 & 1.5 & 1.0 & 1.5 \\
Garlic powder & 1.0 & 1.0 & 1.0 & 15 & 1.0 \\
Stale bread & 15 & 15 & 100 & 15 \\
\hline Total & 100 & 100 & 100 & 100 \\
\hline
\end{tabular}


storage. All analyses were performed in triplicate.

\section{Total phenolic content and antioxidant activity}

The concentration of phenolic compounds in bee pollen was determined by the Folin-Ciocalteau method as described by Singleton and Rossi (1965). Briefly, 100 L of Folin-Ciocalteau reagent was added to $20 \mathrm{~L}$ of ethanol extract. After $5 \mathrm{~min}, 300 \mathrm{~L}$ of $7.5 \mathrm{~g} / 100 \mathrm{~mL}$ sodium carbonate was added to extract. The extract were incubated for $2 \mathrm{~h}$ at room temperature and the absorbance was measured with a UV-VIS spectrophotometer (Helios gamma, Thermo Spectronic, USA) at $760 \mathrm{~nm}$ against a blank reagent. The quantity of total phenolic content in the sample was calculated as gallic acid equivalent.

For ferric reducing antioxidant power (FRAP) determination, extract was mixed with $0.95 \mathrm{~mL}$ ferric-TPTZ reagent (prepared by mixing $300 \mathrm{mM}$ acetate buffer, $\mathrm{pH}$ 3.6, $10 \mathrm{mM} \mathrm{TPTZ}$ in $40 \mathrm{mM} \mathrm{HCl}$, and $20 \mathrm{mM} \mathrm{FeCl}_{3}$ in the ratio 10:1:1, respectively) and measured at $593 \mathrm{~nm}$ (Helios gamma, Thermo Spectronic, USA). $\mathrm{FeSO}_{4}$ was used as a standard and antioxidant power was expressed as $\mathrm{mmol} / \mathrm{g}$ (Gao et al., 2000).

Radical scavenging activity (DPPH) of pollen extract was determined according to Morais et al. (2011) with a slight modification. Briefly, $50 \mu \mathrm{L}$ of the extract were added to $1 \mathrm{~mL}$ of DPPH methanol solution $(100 \mu \mathrm{M})$ and left to stand for $30 \mathrm{~min}$ at room temperature followed by absorbance measurement of the resulting solutions at $515 \mathrm{~nm}$ using a spectrophotometer (Helios gamma). This activity is given as percent DPPH scavenging activity that is calculated as DPPH scavenging activity $(\%)=[$ (control absorbance - extract absorbance) / (control absorbance)] $\times 100$. The extract concentration providing $50 \%$ of DPPH $\left(\mathrm{EC}_{50}\right)$ was calculated by interpolation from the graph of DPPH percentage against extract concentration.

\section{Proximate composition and cooking loss}

Moisture, protein $(\mathrm{N} \times 6.25)$, fat and ash contents of meatballs were determined according to AOAC (2000) procedure. Carbohydrate contents were calculated by difference. For cooking loss, meatballs were cooked in a preheated electrical grill (Arcelik Midi Firin, Turkey) for a total of $10 \mathrm{~min}, 6 \mathrm{~min}$ one side and $4 \mathrm{~min}$ the other side. The weight of three meatballs per batch was measured at room temperature, before and after cooking to calculate cooking loss.

\section{Texture profile analysis}

Texture profile analysis (TPA) was performed accord- ing to the procedure of Saricaoglu and Turhan (2013) using a Texture Analyzer (TA-XT Plus, Stable Micro Systems, UK) with a maximum force of $2 \mathrm{~kg}$. An adaptor, a cylinder with a diameter of $36 \mathrm{~mm}$, was used. The meatballs were put in a cylindrical container with a high of $15 \mathrm{~mm}$ and a diameter of $30 \mathrm{~mm}$. The adaptor was 20 $\mathrm{mm}$ above the sample, and then declining at rate of 30 $\mathrm{mm} / \mathrm{min}$. The adaptor was backed up to the original position after penetrating $10 \mathrm{~mm}$ in depth. The movement of the adaptor was repeated once for completing the measurements. Parameters of TPA, namely hardness, springiness, cohesiveness, gumminess and chewiness were computed. Four different meatballs from each batch were analyzed.

\section{Sensory evaluation}

Meatballs were cooked as previously described and served warm to a trained consumer panel of 8-10 volunteers from the Department of Food Engineering at Ondokuz Mayis University in Turkey. Each sample was coded with randomly selected 3-digit numbers. The sensory evaluations were performed by the panelists under fluorescence lighting. Panelists were instructed to cleanse their palates between samples using water. Each treatment from each replication was evaluated in one separate session given a total of three sessions. Appearance evaluation was performed only on raw samples, while flavor, hardness and juiciness were done on cooked samples. The appearance, flavor, hardness and juiciness of the meatballs were scored using a 9 point Hedonic scale, where 1 represented dislike extremely and 9 represented like extremely. Each attribute was discussed and tests were initiated after the panelists were familiarized with the scales. The overall acceptability was calculated taking into account appearance, flavor, hardness, and juiciness (each with $25 \%$ ).

\section{Fatty acid composition}

Total lipids were extracted by the method of Bligh and Dyer (1959). Fatty acid composition was determined after methylation (ISO, 1978) by GC-MS (Shimadzu model of QP2010 Plus, Shimadzu Corporation, Japan) using a Teknokroma TR-CN 100 column $(60 \mathrm{~m} \times 0.25 \mathrm{~mm}$ I.D., 0.20 $\mu \mathrm{m})$ (Teknokroma, Spain). The temperature of the injector port and detector was held at $250^{\circ} \mathrm{C}$. The injected volume was $1.0 \mu$ l. The carrier gas was helium at a pressure of $200 \mathrm{kPa}$. The split used was 1:100. The temperature of the column was held at $90^{\circ} \mathrm{C}$ for $7 \mathrm{~min}$, raised to $240^{\circ} \mathrm{C}$ at $5^{\circ} \mathrm{C} / \mathrm{min}$ and finally held at $240^{\circ} \mathrm{C}$ for $10 \mathrm{~min}$. Fatty acids were identified by comparison of their retention times 
with those of authentic standards (Supelco 37 Components FAME Mixture, Cat. No. 18919-1AMP, USA) and reported as the percentage of total fatty acids determined.

\section{pH, color and TBA value}

$\mathrm{pH}$ values of meatballs were measured using a digital pH-meter (Cyberscan PC 510, Singapore) equipped with a combination $\mathrm{pH}$ electrode (Sensorex, S175CD Spear Tip, USA) calibrated in buffers at $\mathrm{pH} 4.01$ and 7.00 (Mettler Toledo, USA) at $25^{\circ} \mathrm{C}$. The average of three measurements was used.

The surface color of meatballs was measured using the Hunter Lab system with a colorimeter (Minolta CR 300), calibrated with a white tile (Minolta calibration plate, No. 21733001, $Y=92.6, x=0.3136, y=0.3196)$ at 2 observation angle with a $\mathrm{C}$ illuminant source. Three raw meatballs per batch were randomly selected and three readings were taken from each meatball surface. Hunter $L$ (lightness; $100=$ white, $0=$ black), $a$ (redness; +, red; - , green), $b$ (yellowness; +, yellow; -, blue) values were recorded.

TBA value was determined according to the water vapour distillation method of Tarladgis et al. (1960), and expressed as milligram of malondialdehyde (MDA) per kilogram of sample.

\section{Microbiological analysis}

For microbiological analysis, meatball samples $(10 \mathrm{~g})$ were transferred aseptically into individual stomacher bags, containing $90 \mathrm{~mL}$ of sterile saline solution $(\mathrm{NaCl}$ $0.85 \%$ ) and homogenized in a stomacher for $1 \mathrm{~min}$. For each sample, appropriate serial decimal dilutions were prepared in saline solution $(\mathrm{NaCl} 0.85 \%)$ and the surface plate method was used for enumeration.

The microbiological analyses made on the samples were: total aerobic mesophilic bacteria (TAMB) determined on Plate Count Agar (PCA, Merck) incubated at $28^{\circ} \mathrm{C}$ for $3 \mathrm{~d}$, coliform bacteria on $3 \mathrm{M}$ Petrifilm Coliform Count Plate (Bioser, Barcelona, Spain) incubated at $37^{\circ} \mathrm{C}$ for $24 \mathrm{~h}$ and $S$. aureus on $3 \mathrm{M}$ Petrifilm $S$. aureus Count Plate (Scharlau, Spain) incubated at $37^{\circ} \mathrm{C}$ for $24 \mathrm{~h}$. Results were expressed as $\log _{10} \mathrm{CFU} / \mathrm{g}$.

\section{Statistical analysis}

The experiment was replicated three times. The data obtained from the nutritional (proximate composition, cooking loss, textural properties, sensory scores and fatty acid composition) and storage parameters $(\mathrm{pH}$, color, TBA value and microbiological properties) were analyzed by one-way and two-way ANOVA, respectively, using the SPSS statistical package program (SPSS Inc., USA). Significant differences among the means were compared using the Duncan's Multiple Range test. A significance level of 0.05 was chosen.

\section{Results and Discussion}

\section{Total phenolic content and antioxidant activity of bee pollen}

Phenolic compounds are abundantly found in bee pollen and they may contribute directly to antioxidant activity, because of their redox properties, which allow them to act as reducing agents, hydrogen donors, and singlet oxygen quenchers (Negri et al., 2011). The results showed that the phenolic content of pollen was found at the value of $10.32 \pm 1.01 \mathrm{mg}$ of gallic acid equivalents per gram of pollen. Even though the values for total phenolic content were low compared with other reports on pollen samples from around the world, for example, Poland (Leja et al., 2007) and Portugal pollens (Morais et al., 2011), but there were samples with similar total phenolic compound content (Graikou et al., 2011). This result could be attributable to botanical and geographical origin, season, and extraction procedures of pollen samples.

Antioxidant activity of pollen is generally related to its high phenolic content (Leja et al., 2007), however, according to report of Negri et al. (2011) no correlation between the amount of total phenols and antioxidant activity was found. Thus, qualitative traits may be more important to determine the observed antioxidant effect than the total content of phenols (Negri et al., 2011). The results showed that FRAP and the DPPH $\mathrm{EC}_{50}$ values of pollen were $26.59 \pm 2.40 \mathrm{mmol} / \mathrm{g}$ and $0.48 \pm 0.04 \mathrm{mg} / \mathrm{mL}$, respectively. The FRAP values reported by Graikou et al. (2011) in Greek pollen and the DPPH $\mathrm{EC}_{50}$ values reported by Morais et al. (2011) in Portugal pollen were different than our results which could be attributable the above mentioned factors.

\section{Proximate composition and cooking loss}

The proximate composition and cooking loss values of meatballs formulated with different levels of bee pollen are given in Table 2. Data indicated that the highest moisture content was determined for control meatballs $(p<$ $0.05)$. The moisture contents of samples decreased as the pollen content increased $(p<0.05)$. The lowest protein content was determined for control meatballs as $15.58 \%$ and protein contents of meatballs formulated with pollen ranged from 16.46 to $18.94 \%$. The protein contents of 
Table 2. Proximate composition, cooking loss, texture profile analysis and sensory scores of meatballs formulated with different levels of bee pollen

\begin{tabular}{cccccc}
\hline \hline & & & Bee pollen level (\%) & \\
\cline { 2 - 6 } & Control & 1.5 & 3.0 & 4.5 & 6.0 \\
\hline Proximate composition (\%) & & & & \\
Moisture & $58.03 \pm 0.43^{\mathrm{a}}$ & $57.12 \pm 0.24^{\mathrm{b}}$ & $56.33 \pm 0.38^{\mathrm{c}}$ & $56.05 \pm 0.50^{\mathrm{c}}$ & $55.00 \pm 0.46^{\mathrm{d}}$ \\
Protein & $15.58 \pm 0.21^{\mathrm{d}}$ & $16.46 \pm 0.08^{\mathrm{c}}$ & $16.96 \pm 0.10^{\mathrm{c}}$ & $17.87 \pm 0.66^{\mathrm{b}}$ & $18.94 \pm 0.73^{\mathrm{a}}$ \\
Fat & $20.00 \pm 0.01$ & $20.65 \pm 0.29$ & $20.78 \pm 0.41$ & $20.43 \pm 0.08$ & $19.94 \pm 0.48$ \\
Ash & $2.35 \pm 0.03$ & $2.19 \pm 0.06$ & $2.29 \pm 0.09$ & $2.23 \pm 0.08$ & $2.35 \pm 0.01$ \\
Carbohydrate & $4.03 \pm 0.61$ & $3.58 \pm 0.32$ & $3.64 \pm 0.55$ & $3.42 \pm 0.92$ & $3.77 \pm 1.16$ \\
Cooking loss (\%) & $39.94 \pm 0.31^{\mathrm{a}}$ & $36.49 \pm 0.30^{\mathrm{b}}$ & $33.05 \pm 0.20^{\mathrm{c}}$ & $32.29 \pm 0.13^{\mathrm{c}}$ & $27.04 \pm 0.92^{\mathrm{d}}$ \\
\hline Texture profile analysis & & & & \\
Hardness (N) & $42.52 \pm 2.53^{\mathrm{a}}$ & $39.18 \pm 1.23^{\mathrm{b}}$ & $38.85 \pm 1.91^{\mathrm{b}}$ & $37.39 \pm 1.39^{\mathrm{b}}$ & $33.61 \pm 0.45^{\mathrm{c}}$ \\
Springiness (cm) & $0.58 \pm 0.03^{\mathrm{d}}$ & $0.78 \pm 0.01^{\mathrm{b}}$ & $0.93 \pm 0.01^{\mathrm{a}}$ & $0.66 \pm 0.03^{\mathrm{c}}$ & $0.58 \pm 0.03^{\mathrm{d}}$ \\
Cohesiveness & $0.17 \pm 0.01$ & $0.17 \pm 0.01$ & $0.16 \pm 0.01$ & $0.17 \pm 0.01$ & $0.16 \pm 0.01$ \\
Gumminess (N) & $7.50 \pm 0.54^{\mathrm{a}}$ & $6.79 \pm 0.42^{\mathrm{ab}}$ & $6.33 \pm 0.57^{\mathrm{b}}$ & $6.35 \pm 0.57^{\mathrm{b}}$ & $4.97 \pm 0.36^{\mathrm{c}}$ \\
Chewiness (N.cm) & $4.34 \pm 0.28^{\mathrm{b}}$ & $5.31 \pm 0.36^{\mathrm{a}}$ & $5.93 \pm 0.55^{\mathrm{a}}$ & $4.20 \pm 0.28^{\mathrm{b}}$ & $2.88 \pm 0.24^{\mathrm{c}}$ \\
\hline Sensory scores & & & & \\
Appearance & $7.83 \pm 0.37^{\mathrm{a}}$ & $6.45 \pm 0.12^{\mathrm{b}}$ & $5.66 \pm 0.34^{\mathrm{c}}$ & $4.92 \pm 0.16^{\mathrm{d}}$ & $4.16 \pm 0.15^{\mathrm{e}}$ \\
Flavor & $7.55 \pm 0.34^{\mathrm{a}}$ & $6.10 \pm 0.45^{\mathrm{b}}$ & $5.56 \pm 0.11^{\mathrm{c}}$ & $4.44 \pm 0.16^{\mathrm{d}}$ & $3.04 \pm 0.04^{\mathrm{e}}$ \\
Hardness & $6.16 \pm 0.15^{\mathrm{a}}$ & $6.00 \pm 0.08^{\mathrm{a}}$ & $5.91 \pm 0.26^{\mathrm{a}}$ & $5.54 \pm 0.03^{\mathrm{b}}$ & $4.68 \pm 0.18^{\mathrm{c}}$ \\
Juiciness & $6.74 \pm 0.14^{\mathrm{a}}$ & $6.02 \pm 0.15^{\mathrm{b}}$ & $5.93 \pm 0.03^{\mathrm{b}}$ & $5.35 \pm 0.50^{\mathrm{c}}$ & $4.43 \pm 0.14^{\mathrm{d}}$ \\
Overall acceptability & $7.07 \pm 0.25^{\mathrm{a}}$ & $6.14 \pm 0.16^{\mathrm{b}}$ & $5.77 \pm 0.13^{\mathrm{c}}$ & $5.06 \pm 0.12^{\mathrm{d}}$ & $4.08 \pm 0.02^{\mathrm{e}}$ \\
\hline
\end{tabular}

Values are means standard deviation of three replicates.

${ }^{\mathrm{a}-\mathrm{e}}$ Means in the same row with different superscript letters are different $(p<0.05)$.

Appearance, flavor, hardness and juiciness were scored using a 9 point scale, where 1: dislike extremely and 9: like extremely. The overall acceptability was calculated from these four sensory properties (each with $25 \%$ ).

meatballs increased as the pollen content increased $(p<$ 0.05 ) and this could be attributable to the protein content of pollen, $21.90 \%$. The fat contents of meatballs were close to adjusted level $(p>0.05)$. The moisture, protein and fat contents of all meatballs were within the limits of the Turkish Uncooked Meatball Standard (TSE, 1992). The ash and carbohydrate contents of meatballs were not significantly changed $(p>0.05)$ by the addition of pollen.

Cooking loss occurs by loss of fat and evaporation of moisture. The highest cooking loss was from the control sample because of the high loss of fat and moisture during cooking $(p<0.05)$. The cooking loss of the samples decreased with more pollen addition $(p<0.05)$ because of its high ability to keep moisture and fat in matrix. Similar to our findings, various researchers also reported that nonmeat ingredients such as lemon albedo (Aleson-Carbonell et al., 2005), flaxseed flour (Bilek and Turhan, 2009), rice bran (Huang et al., 2005), okara (Turhan et al., 2007, 2009) and hazelnut pellicle (Turhan et al., 2005) reduced the cooking loss of meatballs.

\section{Texture profile analysis}

Texture profile analysis of meatballs formulated with different levels of bee pollen is given in Table 2. Data indicated that all textural parameters studied were affected by pollen addition $(p<0.05)$, except cohesiveness. Meatballs formulated with pollen were less hard and less gummy $(p<0.05)$ than the control. The hardness and gumminess values of meatballs decreased as the pollen content increased $(p<0.05)$. Addition of pollen apparently modifies structure of meatballs resulting in decreased hardness and gumminess. In addition, hardness and gumminess reduction could be related to water holding ability of pollen. Also, cooking loss values of meatballs supported this conclusion. Similar to our findings, several researchers reported that the addition of non-meat ingredients to meat batter decreased the hardness and/or gumminess of these meat products (Aleson-Carbonell et al., 2005; Kassama et al., 2003). Springiness and chewiness values of meatballs containing $3.0 \%$ pollen were the highest and increasing the level of pollen decreased the springiness and chewiness values of meatballs $(p<0.05)$. This may be partially attributed to physical and chemical characteristics of pollen. However, an exact explanation of the findings is not clear.

\section{Sensory evaluation}

Sensory scores for parameters such as appearance, fla- 
vour, hardness, juiciness and overall acceptability were significantly affected $(p<0.05)$ by the addition of pollen (Table 2). The highest appearance, flavour, juiciness and overall acceptability scores were recorded for the control meatballs. Generally, the sensory scores of meatballs decreased as the pollen content increased $(p<0.05)$ and this decrease was higher with more than $4.5 \%$ pollen addition. Therefore, $4.5 \%$ of pollen is considered optimum for use an enhancer to the nutritive value in meatballs. With increasing of non-meat additives in meat products contents, decreasing of sensory scores were also reported some researchers (Bilek and Turhan, 2009; Huang et al., 2005; Turhan et al., 2005).

\section{Fatty acid composition}

The fatty acid composition of meatballs formulated with different levels of bee pollen is given in Table 3. The SFAs with the highest concentration in these meatballs were palmitic and stearic acid, while the most abundant was oleic acid, with a concentration of 31.97-33.27 g/100 g. MUFAs and PUFAs together accounted for 39.71$41.10 \%$ of the total fatty acids. Of PUFAs, C18:2n-6c was the most abundant $(2.52-4.07 \mathrm{~g} / 100 \mathrm{~g})$. These results are consistent with the fatty acid composition reported elsewhere in ground meat products (Bilek and Turhan, 2009; Yilmaz and Daglioglu, 2003).

Data in Table 3 indicated that C18:0, C18:2n-6c, C18:

Table 3. Fatty acid composition of meatballs formulated with different levels of bee pollen ( $\mathrm{g} / 100 \mathrm{~g}$ fatty acids)

\begin{tabular}{|c|c|c|c|c|c|}
\hline & \multicolumn{5}{|c|}{ "Bee pollen level (\%) } \\
\hline & Control & 1.5 & 3.0 & 4.5 & 6.0 \\
\hline C10:0 & $0.05 \pm 0.02$ & $0.05 \pm 0.02$ & $0.05 \pm 0.01$ & $0.05 \pm 0.02$ & $0.06 \pm 0.01$ \\
\hline C12:0 & $0.05 \pm 0.02$ & $0.06 \pm 0.01$ & $0.07 \pm 0.02$ & $0.06 \pm 0.01$ & $0.07 \pm 0.02$ \\
\hline C13:0 & $0.01 \pm 0.00$ & $0.01 \pm 0.00$ & $0.01 \pm 0.01$ & $0.01 \pm 0.00$ & $0.01 \pm 0.00$ \\
\hline C14:0 & $2.91 \pm 0.11$ & $2.90 \pm 0.10$ & $2.99 \pm 0.10$ & $3.23 \pm 0.49$ & $3.23 \pm 0.38$ \\
\hline C15:0 & $0.46 \pm 0.05$ & $0.49 \pm 0.05$ & $0.49 \pm 0.05$ & $0.47 \pm 0.04$ & $0.46 \pm 0.05$ \\
\hline C16:0 & $27.74 \pm 1.56$ & $27.40 \pm 1.35$ & $28.12 \pm 1.53$ & $28.17 \pm 1.04$ & $28.38 \pm 0.85$ \\
\hline C17:0 & $1.32 \pm 0.10$ & $1.23 \pm 0.09$ & $1.16 \pm 0.11$ & $1.17 \pm 0.11$ & $1.14 \pm 0.09$ \\
\hline C18:0 & $27.49 \pm 0.92^{\mathrm{a}}$ & $27.51 \pm 0.95^{\mathrm{a}}$ & $26.22 \pm 0.55^{\mathrm{ab}}$ & $25.47 \pm 1.16^{\mathrm{b}}$ & $25.27 \pm 1.20^{\mathrm{b}}$ \\
\hline C20:0 & $0.20 \pm 0.05$ & $0.22 \pm 0.05$ & $0.21 \pm 0.06$ & $0.20 \pm 0.06$ & $0.20 \pm 0.06$ \\
\hline $\mathrm{C} 22: 0$ & $0.03 \pm 0.01$ & $0.04 \pm 0.01$ & $0.03 \pm 0.01$ & $0.03 \pm 0.01$ & $0.04 \pm 0.02$ \\
\hline $\mathrm{C} 23: 0$ & $0.01 \pm 0.00$ & $0.03 \pm 0.01$ & $0.03 \pm 0.01$ & $0.02 \pm 0.01$ & $0.02 \pm 0.01$ \\
\hline$\Sigma \mathrm{SFA}^{1)}$ & $60.27 \pm 0.48$ & $59.94 \pm 0.70$ & $59.39 \pm 1.80$ & $58.89 \pm 1.25$ & $58.88 \pm 2.27$ \\
\hline C14:1 & $0.39 \pm 0.12$ & $0.43 \pm 0.10$ & $0.45 \pm 0.09$ & $0.43 \pm 0.13$ & $0.45 \pm 0.13$ \\
\hline C15:1 & $\mathrm{ND}^{5)}$ & $0.01 \pm 0.00$ & $0.02 \pm 0.01$ & $0.01 \pm 0.01$ & $0.02 \pm 0.01$ \\
\hline C16:1 & $2.20 \pm 0.30$ & $2.08 \pm 0.19$ & $2.15 \pm 0.14$ & $2.19 \pm 0.19$ & $2.02 \pm 0.16$ \\
\hline C17:1 & $0.74 \pm 0.20$ & $0.75 \pm 0.10$ & $0.63 \pm 0.11$ & $0.77 \pm 0.19$ & $0.81 \pm 0.11$ \\
\hline C18:1n-9c,t & $33.27 \pm 1.01$ & $33.13 \pm 1.01$ & $32.95 \pm 1.02$ & $32.94 \pm 1.00$ & $31.97 \pm 1.42$ \\
\hline C20:1n-9 & $0.17 \pm 0.05$ & $0.24 \pm 0.06$ & $0.24 \pm 0.05$ & $0.24 \pm 0.05$ & $0.27 \pm 0.10$ \\
\hline C22:1n-9 & ND & $0.01 \pm 0.01$ & $0.01 \pm 0.00$ & $0.01 \pm 0.00$ & $0.02 \pm 0.01$ \\
\hline $\mathrm{C} 24: 1$ & $0.02 \pm 0.01$ & $0.02 \pm 0.01$ & $0.02 \pm 0.01$ & $0.03 \pm 0.01$ & $0.03 \pm 0.01$ \\
\hline$\Sigma \mathrm{MUFA}^{2)}$ & $36.80 \mathrm{v} 1.21$ & $36.69 \mathrm{v} 1.14$ & $36.48 \pm 1.27$ & $36.65 \pm 1.20$ & $35.59 \pm 1.84$ \\
\hline C18:2n-6t & $0.10 \pm 0.01$ & $0.12 \pm 0.01$ & $0.12 \pm 0.01$ & $0.12 \pm 0.01$ & $0.10 \pm 0.01$ \\
\hline C18:2n-6c & $2.52 \pm 0.13^{\mathrm{c}}$ & $2.78 \pm 0.17^{\mathrm{c}}$ & $3.24 \pm 0.23^{\mathrm{b}}$ & $3.43 \pm 0.14^{\mathrm{b}}$ & $4.07 \pm 0.14^{\mathrm{a}}$ \\
\hline C18:3n-3 & $0.23 \pm 0.05^{\mathrm{c}}$ & $0.28 \pm 0.06^{\mathrm{c}}$ & $0.58 \pm 0.05^{b}$ & $0.66 \pm 0.09^{b}$ & $1.02 \pm 0.28^{\mathrm{a}}$ \\
\hline$C 20: 2 n-3$ & $0.02 \pm 0.01$ & $0.03 \pm 0.01$ & $0.02 \pm 0.01$ & $0.02 \pm 0.01$ & $0.02 \pm 0.01$ \\
\hline$C 20: 3 n-6$ & $0.03 \pm 0.01$ & $0.05 \pm 0.01$ & $0.07 \pm 0.01$ & $0.08 \pm 0.01$ & $0.10 \pm 0.06$ \\
\hline$C 20: 5 n-3$ & ND & $0.07 \pm 0.01^{\mathrm{c}}$ & $0.08 \pm 0.02^{\mathrm{c}}$ & $0.13 \pm 0.01^{\mathrm{b}}$ & $0.18 \pm 0.04^{\mathrm{a}}$ \\
\hline$\Sigma \mathrm{PUFA}^{3)}$ & $2.91 \pm 0.18^{\mathrm{c}}$ & $3.35 \pm 0.22^{\mathrm{c}}$ & $4.12 \pm 0.29^{b}$ & $4.46 \pm 0.14^{b}$ & $5.51 \pm 0.43^{\mathrm{a}}$ \\
\hline $\mathrm{P} / \mathrm{S}^{4)}$ & $0.05 \pm 0.01^{\mathrm{c}}$ & $0.05 \pm 0.01^{\mathrm{c}}$ & $0.07 \pm 0.01^{\mathrm{b}}$ & $0.08 \pm 0.01^{\mathrm{b}}$ & $0.09 \mathrm{v} 0.01^{\mathrm{a}}$ \\
\hline$n-6 / n-3$ & $11.84 \pm 2.05^{\mathrm{a}}$ & $8.54 \pm 1.85^{b}$ & $5.16 \pm 0.56^{\mathrm{c}}$ & $4.58 \pm 0.58^{c}$ & $3.65 \pm 0.57^{\mathrm{d}}$ \\
\hline
\end{tabular}

Values are means standard deviation of three replicates.

${ }^{\mathrm{a}-\mathrm{d}}$ Means in the same row with different superscript letters are different $(p<0.05)$.

${ }^{1)} \mathrm{SFA}=$ Saturated fatty acids.

${ }^{2)}$ MUFA=Monounsaturated fatty acids.

${ }^{3)}$ PUFA=Polyunsaturated fatty acids.

${ }^{4)} \mathrm{P} / \mathrm{S}=$ Polyunsaturated fatty acids/saturated fatty acids.

${ }^{5)} \mathrm{ND}=$ No detected. 
3n-3, C20:5n-3 and PUFA contents of meatballs were affected by pollen addition $(p<0.05)$. While $\mathrm{C} 18: 0$ content of meatballs slightly decreased with pollen addition, $\mathrm{C} 18$ : 2n-6c, C18:3n-3, C20:5n-3 and PUFA contents increased $(p<0.05)$. The low amount of $\mathrm{C} 18: 0$ and the high amount of C18:2n-6c, C18:3n-3, C20:5n-3 in bee pollen is responsible for these effects. From a nutritional perspective, $\alpha$-linolenic acid (C18:3n-3) content of control meatballs was $0.23 \mathrm{~g} / 100 \mathrm{~g}$, and ranged between 0.28 and $1.02 \mathrm{~g} /$ $100 \mathrm{~g}$ for meatballs with added pollen. In the human diet, the recommended adequate intake for $\alpha$-linolenic acid is $2.22 \mathrm{~g} /$ day based on a $2000 \mathrm{kcal}$ diet (Simopoulos et al., 1999). Therefore, $100 \mathrm{~g}$ portion of meatballs with added pollen would provide between 13 and $46 \%$ of this recommended intake.

$\mathrm{P} / \mathrm{S}$ and $\mathrm{n}-6 / \mathrm{n}-3$ ratios are thought to be important in relation to the nutritional value of foods for human health
(Bilek and Turhan, 2009; Lopez-Lopez et al., 2011). The recommended healthy $\mathrm{P} / \mathrm{S}$ ratio is above 0.4 (Lopez-Lopez et al., 2011). In the present study, the addition of pollen to meatballs slightly increased the $\mathrm{P} / \mathrm{S}$ ratio $(p<0.05)$, but this increase was lower than recommended value. Higher $\mathrm{P} / \mathrm{S}$ ratios were reported by Ansorena and Astiasaran (2004) in dry-fermented sausages by adding linseed oil and by Bilek and Turhan (2009) in beef patties by adding flaxseed flour. The effect of the $n-6 / n-3$ ratio is probably of more significance than the $\mathrm{P} / \mathrm{S}$ ratio in term of human nutrition (Bilek and Turhan, 2009). There is abundant evidence associating a higher $n-6 / n-3$ ratio with the promotion of pathogenesis of many diseases, including CVD and cancer, and lower ratios with a suppressive effect. Therefore, the dietary recommendation is to reduce this value to less than 4 for prevention of CVD (Lopez-Lopez et al., 2011). In the present study, n-6/n-3 ratio decreased

Table 4. pH, the Hunter Lab attributes and TBA value of meatballs formulated with different levels of bee pollen

\begin{tabular}{|c|c|c|c|c|c|}
\hline & \multirow{2}{*}{ Bee pollen level (\%) } & \multicolumn{4}{|c|}{ Storage time $(\mathrm{d})$} \\
\hline & & 1 & 3 & 6 & 9 \\
\hline \multirow{5}{*}{$\mathrm{pH}$} & Control & $6.58 \pm 0.02^{\mathrm{a} A}$ & $6.57 \pm 0.03^{\mathrm{bA}}$ & $5.98 \pm 0.03^{\mathrm{aB}}$ & $5.56 \pm 0.04^{\mathrm{bC}}$ \\
\hline & 1.5 & $6.51 \pm 0.02^{\mathrm{bB}}$ & $6.61 \pm 0.01^{\mathrm{aA}}$ & $5.70 \pm 0.05^{\mathrm{dC}}$ & $5.76 \pm 0.07^{\mathrm{aC}}$ \\
\hline & 3.0 & $6.48 \pm 0.02^{\mathrm{bB}}$ & $6.59 \pm 0.01^{\mathrm{abA}}$ & $5.79 \pm 0.03^{\mathrm{cC}}$ & $5.47 \pm 0.02^{\mathrm{cD}}$ \\
\hline & 4.5 & $6.34 \pm 0.03^{\mathrm{cB}}$ & $6.49 \pm 0.03^{\mathrm{cA}}$ & $5.96 \pm 0.05^{\mathrm{abC}}$ & $5.71 \pm 0.02^{\mathrm{aD}}$ \\
\hline & 6.0 & $6.37 \pm 0.01^{\mathrm{cA}}$ & $6.40 \pm 0.02^{\mathrm{dA}}$ & $5.91 \pm 0.04^{\mathrm{bB}}$ & $5.59 \pm 0.02^{\mathrm{bC}}$ \\
\hline \multirow{5}{*}{ Hunter $L^{1)}$} & Control & $53.47 \pm 3.01^{\mathrm{ab}}$ & $55.29 \pm 1.03^{\mathrm{a}}$ & $52.48 \pm 1.05^{\mathrm{b}}$ & $55.77 \pm 0.42^{\mathrm{a}}$ \\
\hline & 1.5 & $55.59 \pm 2.62^{\mathrm{a}}$ & $56.07 \pm 1.15^{\mathrm{a}}$ & $56.60 \pm 0.45^{\mathrm{a}}$ & $54.71 \pm 0.42^{\mathrm{a}}$ \\
\hline & 3.0 & $54.47 \pm 1.32^{\mathrm{a}}$ & $53.19 \pm 0.55^{\mathrm{b}}$ & $55.45 \pm 0.34^{\mathrm{a}}$ & $55.47 \pm 2.14^{\mathrm{a}}$ \\
\hline & 4.5 & $52.00 \pm 1.06^{\mathrm{ab}}$ & $52.43 \pm 0.98^{\mathrm{b}}$ & $50.66 \mathrm{v} 0.69^{\mathrm{c}}$ & $51.71 \pm 0.13^{\mathrm{b}}$ \\
\hline & 6.0 & $49.81 \pm 0.86^{\mathrm{bA}}$ & $51.47 \pm 1.35^{\mathrm{bA}}$ & $47.53 \pm 1.51^{\mathrm{dB}}$ & $49.49 \pm 0.35^{\mathrm{cAB}}$ \\
\hline \multirow{5}{*}{ Hunter $a^{2)}$} & Control & $9.94 \pm 1.49^{\mathrm{aB}}$ & $8.82 \pm 0.99^{\mathrm{aB}}$ & $11.74 \pm 0.33^{\mathrm{aA}}$ & $9.58 \pm 0.03^{\mathrm{aB}}$ \\
\hline & 1.5 & $6.79 \pm 0.64^{\mathrm{bD}}$ & $8.69 \pm 0.61^{\mathrm{aC}}$ & $10.66 \pm 0.25^{\mathrm{aA}}$ & $9.70 \pm 0.24^{\mathrm{aB}}$ \\
\hline & 3.0 & $7.15 \pm 0.78^{\mathrm{bB}}$ & $6.02 \pm 0.62^{\mathrm{bC}}$ & $9.23 \pm 1.18^{\mathrm{bA}}$ & $7.53 \pm 0.28^{\mathrm{bB}}$ \\
\hline & 4.5 & $6.59 \pm 0.21^{\mathrm{bB}}$ & $4.95 \pm 0.32^{\mathrm{bcC}}$ & $7.38 \pm 0.39^{\mathrm{cA}}$ & $7.47 \pm 0.37^{\mathrm{bA}}$ \\
\hline & 6.0 & $6.39 \pm 0.63^{\mathrm{bB}}$ & $4.340 \pm .48^{\mathrm{cC}}$ & $7.68 \pm 0.19^{\mathrm{cA}}$ & $7.41 \pm 0.33^{\mathrm{bA}}$ \\
\hline \multirow{5}{*}{ Hunter $b^{3)}$} & Control & $11.74 \pm 0.72^{\mathrm{cA}}$ & $11.56 \pm 0.48^{\mathrm{cA}}$ & $10.54 \pm 0.62^{\mathrm{cB}}$ & $10.19 \pm 0.12^{\mathrm{dB}}$ \\
\hline & 1.5 & $15.05 \pm 0.50^{\mathrm{b}}$ & $15.57 \pm 0.37^{\mathrm{b}}$ & $15.61 \pm 0.62^{b}$ & $14.74 \pm 0.51^{\mathrm{c}}$ \\
\hline & 3.0 & $18.10 \pm 1.09^{\mathrm{a}}$ & $16.67 \pm 0.92^{\mathrm{b}}$ & $17.26 \pm 0.76^{\mathrm{a}}$ & $17.21 \pm 0.93^{\mathrm{b}}$ \\
\hline & 4.5 & $18.64 \pm 1.43^{\mathrm{a}}$ & $18.28 \pm 0.50^{\mathrm{a}}$ & $17.89 \pm 0.46^{\mathrm{a}}$ & $18.08 \pm 0.74^{\mathrm{ab}}$ \\
\hline & 6.0 & $18.92 \pm 0.53^{\mathrm{aA}}$ & $19.27 \pm 0.87^{\mathrm{aA}}$ & $17.39 \pm 0.15^{\mathrm{aB}}$ & $18.71 \pm 0.23^{\mathrm{aA}}$ \\
\hline \multirow{5}{*}{$\mathrm{TBA}^{4)}$} & Control & $0.44 \pm 0.04^{\mathrm{D}}$ & $0.58 \pm 0.05^{\mathrm{aC}}$ & $0.66 \pm 0.03^{\mathrm{aB}}$ & $0.79 \pm 0.01^{\mathrm{aA}}$ \\
\hline & 1.5 & $0.41 \pm 0.08^{\mathrm{B}}$ & $0.48 \pm 0.03^{\mathrm{bB}}$ & $0.56 \pm 0.03^{\mathrm{bA}}$ & $0.60 \pm 0.01^{\mathrm{bA}}$ \\
\hline & 3.0 & $0.38 \pm 0.06^{\mathrm{C}}$ & $0.44 \pm 0.02 b^{\mathrm{cB}}$ & $0.54 \pm 0.03^{\mathrm{bA}}$ & $0.55 \pm 0.04^{\mathrm{cA}}$ \\
\hline & 4.5 & $0.38 \pm 0.03^{\mathrm{C}}$ & $0.40 \pm 0.04^{\mathrm{cdC}}$ & $0.45 \pm 0.01^{\mathrm{cB}}$ & $0.53 \pm 0.01^{\mathrm{cA}}$ \\
\hline & 6.0 & $0.34 \pm 0.01$ & $0.36 \pm 0.03^{\mathrm{d}}$ & $0.36 \pm 0.06^{\mathrm{d}}$ & $0.38 \pm 0.02^{\mathrm{d}}$ \\
\hline
\end{tabular}

Values are means standard deviation of three replicates.

${ }^{\mathrm{a}-\mathrm{d}}$ Means in the same column with different superscript letters are different $(p<0.05)$.

A-D Means in the same row with different superscript letters are different $(p<0.05)$.

${ }^{1)}$ Hunter $L=$ Lightness $(100=$ white, $0=$ black $)$.

${ }^{2)}$ Hunter $a=$ Redness ( + , red; - , green).

${ }^{3)}$ Hunter $b=$ Yellowness (+, yellow; -, blue).

${ }^{4)} \mathrm{TBA}=$ Tthiobarbituric acid (mg MDA/kg sample). 
from 11.84 in control meatball to $3.65-8.54$ in meatballs with added pollen as a consequence of the $\mathrm{C} 18: 3 \mathrm{n}-3$ and C20:5n-3 increment. The addition of pollen to meatballs obviously improved their nutritive value. Lower $n-6 / n-3$ ratios were reported by Ansorena and Astiasaran (2004) in dry-fermented sausages by adding linseed oil, by Bilek and Turhan (2009) in beef patties by adding flaxseed flour and by Valencia et al. (2008) in fresh pork sausages by adding linseed oil, fish oil and natural antioxidants.

\section{pH, color and TBA value}

$\mathrm{pH}$, the Hunter Lab attributes and TBA value of meatballs formulated with different levels of bee pollen are given in Table 4. $\mathrm{pH}$ values of meatball samples were affected by both pollen addition and storage time $(p<0.05)$. While on 1 and $3 \mathrm{~d}$ of storage, in general, $\mathrm{pH}$ values of samples decreased as the pollen content increased, on the other days of storage, different effects were observed. Various researchers also reported that non-meat ingredients such as oat bran (Yilmaz and Daglioglu, 2003), honey (Johnston et al., 2005), okara (Turhan et al., 2007, 2009) and pumpkin (Cucurbitamoschata Duch.) leaf extract (Choe et al., 2011) changed $\mathrm{pH}$ value of meat products. In general, $\mathrm{pH}$ value of control sample decreased during storage, while $\mathrm{pH}$ values of meatballs formulated with bee pollen slightly increased until the $3 \mathrm{~d}$ of storage and then, began to decreased $(p<0.05)$. The decrease in $\mathrm{pH}$ of meatballs during storage might be caused by the action of bacteria, which brings about a breakdown of the carbohydrate into organic acids, mainly lactic acid causing a decrease in $\mathrm{pH}$ (Kumar et al., 2007).

In all storage times, in general, Hunter $L$ values (lightness) of meatballs decreased $(p<0.05)$ as the pollen content increased however, Hunter $L$ values of samples did not change ( $p>0.05)$ during storage except meatballs added with $6 \%$ pollen. Hunter $a$ (redness) values of meatball samples were affected by both pollen addition and storage time ( $p<0.05$ ). In general, Hunter $a$ values of samples decreased as the pollen content increased. This might be a result of a decrease in red meat or an increase in pollen in the formulation. Turhan et al. (2005) and Yilmaz and Daglioglu (2003) obtained similar results in beef burgers with hazelnut pellicle and in meatball with oat bran added, respectively. The changes in Hunter $a$ value of meatballs during storage are not clear. Hunter $b$ values (yellowness) also showed a contrary trend to Hunter $a$ values. The control meatballs had the lowest Hunter $b$ values and Hunter $b$ values of meatballs increased $(p<0.05)$ as the pollen content increased. These results are in agreement with those of the previous studies (Jimenez-Colmenero et al., 2003; Turhan et al., 2007, 2009). Only, Hunter $b$ values of control samples and meatballs with added $6 \%$ pollen changed during storage $(p<0.05)$.

TBA value is one of the most widely used tests for evaluating the lipid oxidation of meat and meat products. TBA values of meatball samples were affected by both pollen addition except $1 \mathrm{~d}$ of storage and storage time except meatballs added with $6 \%$ pollen $(p<0.05)$. On 3, 6 and $9 \mathrm{~d}$ of storage, the highest TBA value was determined in control samples $(p<0.05)$ and in general, TBA value of samples decreased as the pollen content increased $(p<0.05)$. TBA values of meatballs increased during storage $(p<0.05)$ and the increase in control sample was faster and higher level than in the meatballs formulated with pollen. On $9 \mathrm{~d}$ of storage, the increase in TBA value of control and meatballs formulated with 1.5, 3.0 and $4.5 \%$ was $80,46,45$ and $40 \%$, respectively. TBA values of the meatballs formulated with $6 \%$ remained relatively constant during storage $(p>0.05)$. These results indicate that bee pollen is effective in retarding the lipid oxidation of cold stored meatballs. These results are also supported by phenolic content and antioxidant activity of bee pollen. Antioxidant capacity of bee pollen is related to its phenolic compounds. The high ability of phenolic constituents to neutralize the active oxygen species is strongly associated with their structure, such as the conjugated double bonds and the number of hydroxyl groups in the aromatic ring, mostly attributed to flavonoids and cinnamic acid derivates (Leja et al., 2007). Similar to our findings, Freire et al. (2012), Graikou et al. (2011), Morais et al. (2011), Negri et al. (2011) and Rzepecka-Stojko et al. (2012) reported bee pollens have strong antioxidant capacity. Johnston et al. (2005) also reported that clover and wildflower honeys delayed lipid oxidation in readyto-eat ground beef patties.

\section{Microbiological analysis}

Results of the microbiological analyses of the meatballs formulated with different levels of bee pollen during the $9 \mathrm{~d}$ storage time are presented in Table 5. The counts of all determined microbiological indicators were affected by both pollen addition, except $1 \mathrm{~d}$ of storage for $S$. aureus and storage time $(p<0.05)$. On 1 and $3 \mathrm{~d}$ of storage, the highest total aerobic mesophilic bacteria (TAMB) count was observed in control samples, while on 6 and $9 \mathrm{~d}$ of storage, the highest TAMB count was observed control and meatballs added with $1.5 \%$ pollen. In general, TAMB counts of samples decreased as the pollen content increa- 
Table 5. The microbiological properties of meatballs formulated with different levels of bee pollen (Log CFU/g)

\begin{tabular}{cccccc}
\hline \hline & Bee pollen level (\%) & \multicolumn{4}{c}{ Storage time (d) } \\
\cline { 2 - 6 } & Control & $6.45 \pm 0.11^{\mathrm{aC}}$ & $6.80 \pm 0.04^{\mathrm{aB}}$ & $8.05 \pm 0.08^{\mathrm{aA}}$ & $8.19 \pm 0.07^{\mathrm{aA}}$ \\
& 1.5 & $6.36 \pm 0.02^{\mathrm{bD}}$ & $6.71 \pm 0.05^{\mathrm{bC}}$ & $8.05 \pm 0.04^{\mathrm{aB}}$ & $8.12 \pm 0.02^{\mathrm{aA}}$ \\
TAMB $^{1)}$ & 3.0 & $6.29 \pm 0.03^{\mathrm{bD}}$ & $6.47 \pm 0.03^{\mathrm{cC}}$ & $7.87 \pm 0.03^{\mathrm{bB}}$ & $7.96 \pm 0.04^{\mathrm{bA}}$ \\
& 4.5 & $6.26 \pm 0.04^{\mathrm{bD}}$ & $6.43 \pm 0.03^{\mathrm{cC}}$ & $7.70 \pm 0.10^{\mathrm{cB}}$ & $7.95 \pm 0.02^{\mathrm{bA}}$ \\
& 6.0 & $6.26 \pm 0.03^{\mathrm{bD}}$ & $6.40 \pm 0.03^{\mathrm{cC}}$ & $7.68 \pm 0.03^{\mathrm{cB}}$ & $7.94 \pm 0.08^{\mathrm{bA}}$ \\
& Control & $5.98 \pm 0.04^{\mathrm{aD}}$ & $6.39 \pm 0.06^{\mathrm{aC}}$ & $6.58 \pm 0.03^{\mathrm{aB}}$ & $6.71 \pm 0.04^{\mathrm{aA}}$ \\
Coliform bacteria $^{*}$ & 1.5 & $5.87 \pm 0.02^{\mathrm{bC}}$ & $6.28 \pm 0.05^{\mathrm{bA}}$ & $6.12 \pm 0.09^{\mathrm{bB}}$ & $5.86 \pm 0.08^{\mathrm{bC}}$ \\
& 3.0 & $5.75 \pm 0.04^{\mathrm{cBC}}$ & $5.69 \pm 0.06^{\mathrm{cC}}$ & $6.07 \pm 0.06^{\mathrm{bcA}}$ & $5.82 \pm 0.03^{\mathrm{bBB}}$ \\
& 4.5 & $5.75 \pm 0.06^{\mathrm{cB}}$ & $5.73 \pm 0.06^{\mathrm{cB}}$ & $5.98 \pm 0.04^{\mathrm{cdA}}$ & $5.76 \pm 0.04^{\mathrm{cB}}$ \\
& 6.0 & $5.73 \pm 0.05^{\mathrm{cB}}$ & $5.73 \pm 0.03^{\mathrm{cB}}$ & $5.96 \pm 0.03^{\mathrm{dA}}$ & $5.66 \pm 0.04^{\mathrm{dC}}$ \\
& Control & $4.58 \pm 0.09^{\mathrm{C}}$ & $5.38 \pm 0.02^{\mathrm{aB}}$ & $5.77 \pm 0.06^{\mathrm{aA}}$ & $5.83 \pm 0.03^{\mathrm{aA}}$ \\
& 1.5 & $4.49 \pm 0.05^{\mathrm{C}}$ & $5.13 \pm 0.03^{\mathrm{bB}}$ & $5.27 \pm 0.02^{\mathrm{bA}}$ & $5.26 \pm 0.04^{\mathrm{bA}}$ \\
& 3.0 & $4.48 \pm 0.05^{\mathrm{D}}$ & $5.02 \pm 0.04^{\mathrm{cB}}$ & $5.10 \pm 0.01^{\mathrm{cA}}$ & $4.63 \pm 0.03^{\mathrm{cC}}$ \\
& 4.5 & $4.46 \pm 0.04^{\mathrm{B}}$ & $5.00 \pm 0.03^{\mathrm{cA}}$ & $5.02 \pm 0.01^{\mathrm{dA}}$ & $4.25 \pm 0.05^{\mathrm{dC}}$ \\
& 6.0 & $4.47 \pm 0.03^{\mathrm{B}}$ & $5.00 \pm 0.04^{\mathrm{cA}}$ & $5.01 \pm 0.02^{\mathrm{dA}}$ & $4.26 \pm 0.03^{\mathrm{dC}}$ \\
\hline
\end{tabular}

Values are means standard deviation of three replicates.

${ }^{\mathrm{a}-\mathrm{d}}$ Means in the same column with different superscript letters are different $(p<0.05)$.

${ }^{A-D}$ Means in the same row with different superscript letters are different $(p<0.05)$.

${ }^{1)} \mathrm{TAMB}=$ Total aerobic mesophilic bacteria.

sed and on $9 \mathrm{~d}$ of storage, the lowest count was observed in meatballs added with $3.0,4.5$ and $6 \%$ pollen. In general, TAMB counts of meatballs increased during storage. Microbial spoilage of meat usually occurs when TAMB count reaches $10^{8} \mathrm{CFU} / \mathrm{g}$ (Ozturk et al., 2010). TAMB counts of control and meatballs added with $1.5 \%$ pollen exceeded $8 \mathrm{Log} \mathrm{CFU} / \mathrm{g}$ on $6 \mathrm{~d}$ of storage, while TAMB counts of meatballs added with 3.0, 4.5 and $6.0 \%$ approached this value on $9 \mathrm{~d}$ of storage.

In all storage times, the highest coliform bacteria and $S$. aureus counts were in the control meatballs and the lowest in the samples added with pollen. In general, these bacteria counts decreased as the pollen content increased and the decrease was higher than TAMB counts. Coliform bacteria and $S$. aureus counts of meatballs fluctuated during storage. It is obvious from the present studies that bee pollen inhibited the bacterial growth. The antibacterial effect of pollen could be attributed mainly to the high content of flavonoids such as quercetin and kaempferolglucosides which are known to possess antibacterial activity (Graikou et al., 2011). The antimicrobial activity of pollen was also confirmed by several researchers (Basim et al., 2006; Graikou et al., 2011; Morais et al., 2011).

\section{Conclusions}

The results of this study indicate that bee pollen addition had a significant effect on the nutritional and storage quality of meatballs. The addition of pollen improved cooking loss, PUFA content, and P/S and n- $6 / \mathrm{n}-3$ ratios. Moreover, the addition of pollen minimized lipid oxidation and inhibited microbial growth during storage time. However, addition of pollen decreased sensory scores and Hunter $a$ values. Generally, the sensory scores of meatballs decreased with more than $4.5 \%$ pollen addition. Thus, bee pollen could be added to enhance the nutritional and storage quality of meatballs with minimal changes in composition and/or sensory properties.

\section{Acknowledgements}

The authors would like to thank Ondokuz Mayis University Research Foundation (PYO.MUH.1901.12.018) for financial support.

\section{References}

1. Aleson-Carbonell, L., Fernandez-Lopez, J., Perez-Alvarez, J. A., and Kuri, V. (2005) Characteristics of beef burgers as influenced by various types of lemon albedo. Innovat. Food Sci. Emerg. Tech. 6, 247-255.

2. Ansorena, D. and Astiasaran, I. (2004) The use of linseed oil improves nutritional quality of the lipid fraction of dry-fermented sausages. Food Chem. 87, 69-74.

3. AOAC (2000) Official Methods of Analysis. 17th ed, Association of Official Analytical Chemists, Washington, DC, pp. $1-8$.

4. Arihara, K. (2006) Strategies for designing novel functional 
meat products. Meat Sci. 74, 219-229.

5. Basim, E., Basim, H., and Ozcan, M. (2006) Antibacterial activities of Turkish pollen and propolis extracts against plant bacterial pathogens. J. Food Eng. 77, 992-996.

6. Bilek, A. E. and Turhan, S. (2009) Enhancement of the nutritional status of beef patties by adding flaxseed flour. Meat Sci. 82, 472-477.

7. Bligh, E. G. and Dyer, W. J. (1959) A rapid method of total lipid extraction and purification. Can. J. Biochem. Phys. 37, 911-917.

8. Choe, J. H., Kim, H. Y., Choi, Y. S., Han, D. J., Choi, J. H., Kim, Y. J., and Kim, C. J. (2011) Effect of pumpkin (Cucurbitamoschata Duch.) leaf ethanolic extracts on lipid oxidation and microbial activity in refrigerated raw ground pork. Korean J. Food Sci. An. 31, 865-871.

9. Dzudie, T., Kouebou, C. P., Essia-Ngang, J. J., and Mbofung, C. M. F. (2004) Lipid sources and essential oils effects on quality and stability of beef patties. J. Food Eng. 65, 67-72.

10. Fernandez-Gines, J. M., Fernandez-Lopez, J., Sayas-Barbera, E., and Perez-Alvarez, J. A. (2005) Meat products as functional foods: A review. J. Food Sci. 70, 37-43.

11. Freire, K. R. L., Lins, A. C. S., Dorea, M. C., Santos, F. A. R., Camara, C. A., and Silva, T. M. S. (2012) Palynological origin, phenolic content, and antioxidant properties of honeybee-collected pollen from Bahia, Brazil. Molecules 17, 16521664.

12. Gao, X., Björk, L., Trajkovski, V., and Uggla, M. (2000) Evaluation of antioxidant actives of rosehip ethanol extracts in different test systems. J. Agr. Food Chem. 80, 2021-2027.

13. Graikou, K., Kapeta, S., Aligiannis, N., Sotiroudis, G., Chondrogianni, N., Gonos, E., and Chinou, I. (2011) Chemical analysis of Greek pollen-Antioxidant, antimicrobial and proteasome activation properties. Chem. Cent. J. 5, 1-9.

14. Huang, S. C., Shiau, C. Y., Liu, T. E., Chu, C. L., and Hwang, D. F. (2005) Effects of rice bran on sensory and physic-chemical properties of emulsified pork meatballs. Meat Sci. 70, 613-619.

15. International Organization for Standardization, ISO (1978) Animal and Vegetable Fats and Oils - Preparation of Methyl Esters of Fatty Acids. Method ISO 5509. Geneve, p. 6.

16. Jimenez-Colmenero, F., Carballo, J., and Cofrades, S. (2001) Healthier meat and meat products: their role as functional foods. Meat Sci. 59, 5-13.

17. Jimenez-Colmenero, F., Serrano, A., Ayo, J., Solas, M. T., Cofrades, S., and Carballo, J. (2003) Physicochemical and sensory characteristics of restructured beef steak with added walnuts. Meat Sci. 65, 1391-1397.

18. Johnston, J. E., Sepe, H. A., Miano, C. L., Brannan, R. G., and Alderton, A. L. (2005) Honey inhibits lipid oxidation in readyto-eat ground beef patties. Meat Sci. 70, 627-631.

19. Kassama, L. S., Ngadi, M. O., and Raghavan, G. S. V. (2003) Structural and instrumental textural properties of meat patties containing soy protein. Int. J. Food Prop. 6, 519-529.

20. Kumar, R. R., Sharma, B. D., Kumar, M., Chidanandaiah, and Biswas, A. K. (2007) Storage quality and shelf life of vacu- um-packaged extended chicken patties. J. Muscle Foods 18, 253-263.

21. Leja, M., Mareczek, A., Wyzgolik, G., Klebacz-Baniak, J., and Czekonska, K. (2007) Antioxidative properties of bee pollen in selected plant species. Food Chem. 100, 237-240.

22. Lopez-Lopez, I., Cofrades, S., Caneque, V., Diaz, M. T., Lopez, O., and Jimenez-Colmenero, F. (2011) Effect of cooking on the chemical composition of low-salt, low-fat Wakame/ olive oil added beef patties with special reference to fatty acid content. Meat Sci. 89, 27-34.

23. Morais, M., Moreira, L., Feas, X., and Estevinho, L. M. (2011) Honeybee-collected pollen from five Portuguese Natural Parks: Palynological origin, phenolic content, antioxidant properties and antimicrobial activity. Food Chem. Toxicol. 49, 1096-1101.

24. Nagai, T., Inoue, R., Kanamori, N., Suzuki, N., and Nagashima, T. (2006) Characterization of honey from different floral sources. Its functional properties and effects of honey species on storage of meat. Food Chem. 97, 256-262.

25. Negri, G., Teixeira, E. W., Alves, M. L. T. M. F., Moreti, A. C. C. C. M., Otsuk, I. P., Borguini, R. G., and Salatino, A. (2011) Hydroxycinnamic acid amide derivates, phenolic compounds and antioxidant activities of extracts of pollen samples from Southeast Brazil. J. Agr. Food Chem. 59, 55165522.

26. Rzepecka-Stojko, A., Pilawa, B., Ramos, P., and Stojko, J. (2012) Antioxidative properties of bee pollen extracts examined by EPR spectroscopy. J. Apic. Sci. 56, 23-30.

27. Sanchez-Escalante, A., Torrescano, G., Djenane, D., Beltran, J. A., and Roncales, P. (2003) Stabilisation of colour and odour of beef patties by using lycopene-rich tomato and peppers as a source of antioxidants. J. Sci. Food Agric. 83, 187194.

28. Saricaoglu, F. T. and Turhan, S. (2013). Chemical composition, colour and textural properties of Akcaabat meatball: a traditional Turkish meat product. Gida, 38, 191-198.

29. Simopoulos, A. P., Leaf, A., and Salem, N. (1999) Workshop on the essentiality of and recommended dietary intakes for omega-6 and omega-3 fatty acids. J. Am. Coll. Nutr. 18, 484489.

30. Singleton, V. L. and Rossi, J. A. (1965) Colorimetry of total phenolic with phosphomolybdic and phosphotungstic acid reagent. Am. J. Enol. Viticult. 16, 144-158.

31. TSE (1992) Turkish Uncooked Meatball Standard, TSE 10581. Turkish Standard Institute. Ankara, Turkey, pp. 1-11.

32. Turhan, S., Sagir, I., and Ustun, N. S. (2005) Utilization of hazelnut pellicle in low-fat beef burgers. Meat Sci. 71, 312316.

33. Turhan. S., Temiz, H., and Sagir, I. (2007) Utilization of wet okara in low-fat beef patties. J. Muscle Foods 18, 226-235.

34. Turhan, S., Temiz, H., and Sagir, I. (2009) Characteristics of beef patties using okara powder. J. Muscle Foods 20, 89-100.

35. Tarladgis, B. G., Watts, B. M., and Younathan, M. T. (1960) A distillation method for the quantitative determination of malonaldehyde in rancid foods. J. Am. Oil Chem. Soc. 37, 44-48.

36. Valencia, I., O'Grady, M. N., Ansorena, D., Astiasaran, I., and 
Kerry, J. P. (2008) Enhancement of the nutritional status and quality of fresh pork sausages following the addition of linseed oil, fish oil and natural antioxidants. Meat Sci. 80, 10461054.
37. Yilmaz, I. and Daglioglu, O. (2003) The effect of replacing fat with oat bran on fatty acid composition and physicochemical properties of meatballs. Meat Sci. 65, 819-823.

(Received 2014.4.18/Revised 2014.6.5/Accepted 2014.6.16) 